\title{
Genetic determinants of autism spectrum disorders - a review
}

\author{
Genetyczne uwarunkowania zaburzeń ze spektrum autyzmu - przegląd badań
}

Paweł Stanicki ${ }^{1}$ ABDEF, https://orcid.org/0000-0002-4942-9030,

Konrad Goliszek ${ }^{1}$ BDEF, https://orcid.org/0000-0001-5149-6059,

Karol Kasprzak ${ }^{1}$ BDEF, https://orcid.org/0000-0003-2698-184X,

Agata Makarewicz ${ }^{2}$ CE, https://orcid.org/0000-0002-4478-8608,

${ }^{1}$ Student Research Group at the I Department of Psychiatry, Psychotherapy and Early Intervention, Medical University of Lublin, Poland

${ }^{2}$ I Department of Psychiatry, Psychotherapy and Early Intervention, Medical University of Lublin, Poland

\begin{abstract}
Introduction: It is estimated that various types of abnormalities from the autistic spectrum disorder occur in up to $2 \%$ of the population. These include difficulties in maintaining relationships, communication, and repetitive behaviours. Literature describes them quite well, in contrast to the causes of these disorders, which include both environmental factors and a very long list of genetic aberrations.

Materials and methods: The papers available on the PubMed platform and other sources were reviewed to describe the most important genetic factors responsible for the development of autism spectrum disorders.

Results: There are many genes and their mutations associated with the prevalence of autism spectrum disorders in patients. One of the main factors is the SHANK gene family, with the type and degree of abnormality in patients depending on the damage to particular genes: SHANK1-SHANK3. Research also shows the potential of targeted symptom-relieving therapies in patients with SHANK3 mutations. A correlation with the occurrence of autism has also been demonstrated for genes responsible for calcium signaling - especially the group of IP3R calcium channels. Their calcium transmission is abnormal in the majority of patients with autism spectrum disorders. A number of mutations in the 7q region were discovered - including the AUTS2, GNAI1, RELN, KMT2E, BRAF genes - the occurrence of which is associated with the presence of symptoms of autism. Autism spectrum disorders occur in about $10 \%$ of patients suffering from monogenic syndromes such as fragile $\mathrm{X}$ chromosome syndrome, Timothy syndrome, tuberous sclerosis, Rett syndrome or hamartomatic tumor syndrome.

Conclusions: Research shows that many mutations can contribute to the development of autism spectrum disorders. Further studies are necessary to discover their therapeutic and diagnostic potential for autism.
\end{abstract}

Keywords: autistic disorder, calcium signaling, chromosomes, human, pair 7, genetic disorder

\section{Streszczenie}

Wstęp: Szacuje się, że różnego rodzaju nieprawidłowości ze spektrum zaburzeń autystycznych występują u nawet 2\% populacji. Są to między innymi trudności w utrzymaniu relacji, komunikacji czy powtarzalne zachowania. Literatura opisuje je dość dobrze, w przeciwieństwie do przyczyn tychże zaburzeń, które to obejmują zarówno czynniki środowiskowe jak i bardzo długą listę aberracji genetycznych.

Materiał i metody: Dokonano przeglądu prac dostępnych na platformie PubMed oraz innych źródeł celem opisania najważniejszych czynników genetycznych odpowiedzialnych za rozwój zaburzeń za spektrum autyzmu.

Dyskusja: Istnieje wiele genów i ich mutacji związanych z występowaniem zaburzeń ze spektrum autyzmu u pacjentów. Jako jeden z głównych czynników wymienia się rodzinę genów SHANK, przy czym rodzaj i stopień nieprawidłowości u pacjentów jest zależny, od uszkodzenia poszczególnych genów: SHANK1-SHANK3. Badania wskazują również na potencjał terapii celowanych łagodzących objawy o pacjentów z mutacjami SHANK3. Związek z występowaniem autyzmu wykazano również dla genów odpowiedzialnych za sygnalizację wapniową - szczególnie grupie kanałów wapniowych IP3R. Przekaźnictwo wapniowe w 
ich obrębie jest nieprawidłowe u większości przypadków pacjentów z zaburzeniami ze spektrum autyzmu. Wskazano szereg mutacji w regionie 7q - w tym geny AUTS2, GNAI1, RELN, KMT2E, BRAF - których występowanie jest wiązane z występowaniem objawów autyzmu. Zaburzenia ze spektrum autyzmu występują u około 10\% pacjentów dotkniętych jednogenowymi zespołami chorobowymi takimi jak zespół łamliwego chromosomu X, zespół Timothyego, stwardnienie guzowate, zespół Retta czy zespół guzów hamartomatycznych.

Wnioski: Badania pokazują, iż bardzo wiele mutacji może przyczynić się do powstawania zaburzeń ze spektrum autyzmu. Dalsze analizy są konieczne celem wykrycia genów o potencjale terapeutycznym i diagnostycznym autyzmu.

Słowa kluczowe: autyzm, sygnalizacja wapniowa, chromosomy ludzkie, para 7, zaburzenie genetyczne

\section{Introduction}

Autism spectrum disorder (ASD) includes a number of different neurodevelopmental disorders usually occurring in early childhood and manifested by difficulties in maintaining relationships, communication and limited, repetitive behavior [1]. Epidemiological studies indicate the occurrence of this disorder in $0.62-0.70 \%$ of the population, however, the latest estimates point to a percentage of up to $2 \%$. Autism affects 4 to 5 times more boys than girls. The pathogenesis of this disease is complex. Researchers indicate the presence of both genetic and environmental factors as well as the interaction of genetic and environmental causes that result in the development of autism spectrum disorders [2]. This paper describes the most important genetic factors identified so far that may contribute to non-neurotypical development resulting in ASD.

\section{Material and methods}

In order to analyze the world bibliography of the topic, the full-text Pubmed database of the last 17 years was searched. The following keywords were used: autism, SHANK, calcium signaling, 7q, monogenic diseases, genetic disorders. Search results for 43 full-text articles were obtained. On this basis, the latest research in the field of genetics and autism is described.

\section{Data from analysis}

SHANK genes

The SHANK gene family consists of: SHANK1 (19q13.33), SHANK2 (11q13.2) and SHANK3 (22q13.3). These are the genes that code large skeletal proteins components of the postsynaptic density (PSD) complexes in the brain. Studies on rodents have shown that they are related to the proper cognitive functioning, excitability, communication and social interactions [3]. Their mutations are responsible for $\sim 1 \%$ of autism cases and have been found in patients across the entire ASD spectrum [4]. In addition, research indicates that, apart from autism, disorders within the SHANK gene family may also cause other diseases such as schizophrenia, Alzheimer's disease, and bipolar disorder [3].
Experiments on mice show that depending on which of the SHANK genes is damaged, different behavioral changes will appear in the test animals. In the case of selective damage to SHANK1, the degree of involvement in social interactions is reduced and the ability to recognize objects is severely impaired [5], at the same time, a study on mice by Ha et al. showed that the SHANK2 gene is most likely associated with motor coordination and specific, repetitive and anxiety behaviors, but not with typically autistic symptoms such as difficulties in establishing social relations or constant repetition of the same activities [6]. First described in Phelan-McDermid syndrome (22q13.3 deletion), which is characterized by a general developmental delay [7], the SHANK3 mutation is considered to cause the most severe cognitive impairment of all genes from the SHANK family. It is also more common than mutations of the other two SHANK genes [8]. Studies by Pagani et al. have shown that the carrier of the SHANK3 mutation is associated with impaired prefrontal cortex function, which researchers associate directly with the presence of a social and communication deficit [9]. Similarly, a study conducted by Peça et al. involving two genetic lines of mice with different SHANK3 lesions confirmed the weakening of social behavior in rodents to an extent depending on the gene fragment that was damaged [10].

Better understanding of the relationship between SHANK gene mutations and the development of ASD may contribute to the development of treatments for autism spectrum disorders that target these mutations. A study by Qin et al. Demonstrated the effectiveness of romidepsin (a class I histone deacetylase inhibitor) in alleviating social behavior deficit in mice with SHANK3 deficiency [11]. Similarly, researchers led by Bidinosti demonstrated the effectiveness of CDC-like kinase 2 (CLK2) inhibitors in restoring social functions in mice with a SHANK3 deficiency [12].

\section{Calcium channels encoding genes}

Many studies have shown that ASD is often caused by genes related directly or indirectly to the control of intracellular calcium levels or proteins regulated by 
an increase in intracellular calcium levels. These genes encode ion channels, neurotransmitter receptors and calcium-regulated signaling proteins essential for the development of the central nervous system [13].

In neurons, calcium channels are particularly important in initiating and propagating of action potentials. When the potential reaches the presynaptic membrane, local voltage dependent calcium receptors open up, causing an influx of calcium ions enhanced by the release of intracellular calcium stores. This leads to the fusion of vesicles containing neurotransmitters with the presynaptic membrane, causing the release of the neurotransmitter into the synaptic space [14].

In recent years, a study has been carried out to investigate the correlation between high throughput of calcium signaling and ASD symptoms (tested with the ADOS-2 test, which is the golden standard in the autism diagnosis). A ROC curve was made to assess the quality of the classifier. An AUC score of 0.85 indicates that calcium signaling analysis may be a reliable diagnostic test for these disorders, although additional cohort studies using larger groups of patients are needed [14].

The research assigned a special role to the group of IP3R calcium channels. They are concentrated mainly in the endoplasmic reticulum, which is the main store of intracellular calcium. These channels are made up of three different gene products (IP3Rs types 1-3). In neurons, IP3R-mediated calcium release influences plasticity and synaptic memory $[15,16]$, neuronal excitability $[17,18]$, neurotransmitter release $[19,20]$, axon growth [21] and long-term changes in gene expression [28] . Depending on the part of the brain, different isoforms of IP3R are expressed to varying degrees. For example, Purkinje cells in the cerebellum express IP3R1 high, but have low or undetectable levels of IP3R3. In contrast, cerebellar granule cells and many medullary regions show moderately high levels of IP3R3, while IP3R1 is virtually undetectable in these regions [14]. IP3R shows a high level of expression in the cerebellum and this is where it was first detected by scientists. Interestingly, in research studies dysfunction of the cerebellum has been associated with autism [22]. The findings discussed in one review indicate that IP3R-mediated signaling is disrupted in most ASD cases, indicating the endoplasmic reticulum as a functional "center" at which various cell signaling pathways converge to contribute to pathogenesis of ASD [14].

\section{Correlation of mutations in the $7 q$ region with autism}

Chromosome 7 is classified as a submetacentric chromosome, and therefore has a centromere near the center of the chromosome. This means that its upper arms - p are shorter than the lower arms - q [23]. One of the first studies to link autism to the q arm of chromosome 7 was conducted in 1989 by Molecular Genetic study Autism Consortium [24]. Subsequent research led to the discovery of regions whose mutations may be responsible for the occurrence of autism to a large extent.

In the 7q11.22 region there is the AUTS2 gene [25], the function of which in the human body is still insufficiently understood. Studies in mice have shown that gene's strong expression in the body of the fetus is observed in the areas associated with higher functions of the brain, i.e. the neocortex, hippocampus and cerebellum, and that it is involved in the formation of the spinal cord [26]. Its proper functioning is necessary for the proper migration of neurons and the development of the cortex [27]. Its dysfunction is associated with the occurrence of epilepsy [28], developmental delay [29] and autism. The latter disease in particular is confirmed by recent studies. There are indications that mutations in the AUTS2 gene may significantly contribute to the onset of autism. According to a study by Husson et al., AUTS2 was classified as class B. $(10 \%<\mathrm{FDR}<5 \%)$, which means that it is probably associated with autism. It is worth adding that the gene contains the region of the greatest statistical importance in differentiating Homo sapiens from Neanderthals and other primates. This gene has therefore changed significantly during the evolution of the human species [30].

The GNAI1 gene is located in the 7q21.11 region [31]. The protein it encodes is the alpha subunit of the inhibitory complex that responds to beta-adrenergic signals by inhibiting adenylate cyclase. A study by Satterstrom et al. identified this gene as a candidate for autism with a false detection rate (FDR) between 0.01 and 0.05 (0.01 $<$ FDR 0.05 ) meaning there is a $95 \%$ chance for a positive correlation [32].

The RELN and GIGYF1 genes are located in the 7q22.1 region [33]. The main function of the RELN gene is to control the migration of neurons and their positioning during the development of the central nervous system [34]. De Rubeis et al., analyzing 3871 patients, showed that there is a $95 \%$ chance of correlating the RELN gene with autism [35].

The KMT2E gene is located in the $7 q 22.3$ region [36]. It has been shown to play a key role in many biological processes, including the cell cycle, the maintenance of genome stability, adult hematopoiesis and spermatogenesis [37]. It is speculated that it may play a significant role in the development of the cerebral cortex, as its expression is high in prenatal life [38] and its mutation may contribute to the onset of autism [39].

The association with ASD has also been demonstrated for the KMT2C gene [40], which in the human body encodes the histone-lysine N-methyltransferase $2 \mathrm{C}$, which binds 
one methyl group to the lysine 4 of histone H3, thus leading to the activation of transcription. The molecular function of KMT2C has been explored by studying its orthologs (trr and G9a) in Drosophila mites [41]. KMT2C was also identified in an ASD whole exome sequencing study and subsequent transmission and de novo association (TADA) analysis as a highly enriched variant gene that may affect the risk of ASD with a false detection rate (FDR) $<0.1$ [35] .

The FOXP2 gene, located in 7q31.1 region provides the information necessary for the synthesis of the forkhead box P2 protein. It is active in both prenatal and postnatal life in the brain. Research suggests that it has an important role in its development, including the effect on the growth of neurons and the transmission of signals between them, as well as on their plasticity (the ability to create new connections between neurons, essential in the learning process). It also seems that this gene is important in the development of speech and language [42]. FOXP2 activation occurs through the degradation of serotonin by monoaminoxygenase $\mathrm{A}$, encoded by the MAOA gene. A mutation of this gene (leading to a reduction in its encoded monoamine oxidase) and a mutation of FOXP2 occurring together are associated with the occurrence of autism. Correlation does not occur when these mutations occur separately [43].

The BRAF gene (located in the $7 \mathrm{q} 34$ region) in the human body is responsible for encoding a protein belonging to the raf / mil serine-threonine protein kinase family [44]. Its mutations are associated mainly with cardio-facial-cutaneous syndrome, which presents with heart defects, developmental delay and craniofacial deformities [45], as well as an increased incidence of cancers, including lymphomas. One of the newest studies shows that changes in this gene may contribute significantly to the occurrence of autism [32].

\section{ASD in monogenetic syndromes}

Autism spectrum disorders are present in many monogenic syndromes, and about $10 \%$ of people with ASD have symptoms that meet the criteria of a syndrome caused by a single mutation [46].

\section{Fragile X syndrome - FMR1}

One example is a fragile $\mathrm{X}$ syndrome called Martin Bell syndrome. The number of $25 \%$ of people with this syndrome present disorders from the spectrum of autism [47]. A dynamic mutation in the FMR1 gene is responsible for it. It consists of the duplication of a gene segment with a sequence of three CGG nucleotides. If the number of repetitions is $65-200$, it is a premutation that usually does not show symptoms of the disease, but tends to lengthen with subsequent generations. If the number of repetitions exceeds 200, then it is a complete mutation that causes symptoms in all boys and about half of the girls with it. This gene encodes the FMRP protein, most present in the brain, which is essential for proper mental development and fertility in women. Its role is to regulate the transport and translation of mRNA in the brain, which is important in synaptic plasticity. FMR1 is one of the three autismrelated genes studied that increases its expression in infancy and childhood [47]. One study found a new variant of a nonsense mutation in the FMR1 gene. It is located in the NES domain of this gene and leads to protein accumulation, possibly disrupting the postsynaptic compartment in neurons. The boy in whom the mutations were detected was intellectually delayed, had problems in interpersonal relations and behavioral disorders [48].

\section{Timothy syndrome - CACNA1C}

A rare disease, Timothy's syndrome, results from a mutation in the CACNA1C gene. It is a gene located on the 12th chromosome and is responsible for the formation of one of the calcium channels. The mutation causes the dysfunction of this channel, which results mainly in dangerous arrhythmias usually leading to death in early childhood [49]. Of the patients who survived long enough to make a diagnosis, $60-80 \%$ presented symptoms of autism [47]. Mutations in other genes from this family (CACNA1D-CACNA1H) are also responsible for various autism-related dysfunctions $[50,51]$.

\section{Tuberous sclerosis - TSC1 and TSC2}

In the case of patients with tuberous sclerosis, which is manifested by the presence of numerous organ changes, usually hamartoma or hamartia, the percentage of people with autism is about $20 \%$. It is a genetic disease resulting from loss-of-function mutations of the TSC1 and TSC2 genes. These genes act as inhibitors of the mTOR complex - a kinase whose function is to regulate cell growth, proliferation and movement as well as translation and transcription processes. The mTOR pathway is crucial in controlling local translation at synapses [46].

\section{Rett syndrome - MECP2}

Rett syndrome is a genetically determined disease, mainly X-linked. It is characterized by disturbances in the development of the nervous, locomotor and digestive systems [52].

It occurs at a frequency of 1 in 10,000 to 15,000 . Population studies conducted in Texas (USA) reported that it affects 1 in 22,800 women aged from 2 to 18 [52]. Initially, it was thought that it occurs only in women, and in men it is a lethal disease, however, the latest studies indicate that it can also occur in men [53], but they develop symptoms faster and more severely than women. Sometimes it can be associated with Klinefelter's 
syndrome - such men have symptoms similar to those of affected women [54].

In 1999, Hudy Zoghbi [55] discovered that the main cause of Rett syndrome (in as many as $95 \%$ of cases) is a mutation in the MECP2 gene located on the $\mathrm{X}$ chromosome in the q28 region [56]. In $90 \%$ of cases it is an inherited mutation, in other cases it is caused by microdeletions and microduplications of critical regions on the X chromosome. The mechanism by which a mutation in the MECP2 gene leads to Rett syndrome is still unknown [56].

It has been shown that the MECP2 protein under certain conditions stimulates the expression of the gene encoding the brain-derived neutropic factor, necessary for the functioning of the nervous system in both adults and fetuses, where it is involved in the maintenance of normal neurogenesis. Disturbance of MECP2 expression has a negative impact on the formation and stabilization of synapses - synaptic plasticity - responsible mainly for learning and memory processes [57].

Patients have normal development of the nervous and mental systems during the first 6-18 months after birth. The disease begins to manifest itself after this period - it is characterized by several stages: stagnation (6-18 months), sudden progression (age 1-4), pseudo-stationary (preschool and school age), stabilization phase (from age 15 to death). Characteristic symptoms of Rett syndrome are loss of previously acquired speech and motor skills. Stereotypical hand movements, breathing disorders and convulsions appear [58].

Symptoms similar to autism are observed in such patients: social withdrawal (in the regression phase), avoidance of eye contact [59], which is why it was previously classified as autism spectrum disorders [60]. More recent studies show differences between the two diseases. Autism is more common in men, patients suffering from it have much worse eye contact with other people and regress to a much lesser extent. These patients' gait and manual skills, unlike patients 'with Rett syndrome, are not impaired. Also, breathing disorders occur very rarely in these patients [59].

\section{PTEN hamartoma tumor syndromes}

PTEN-associated hamartoma tumor syndromes (PHTS) are a group of rare clinical syndromes characterized by germline mutations in the PTEN suppressor gene. In PHTS, cell hyperplasia causes benign hamartomatic changes in many organs [61]. Recent studies have shown that $25-50 \%$ of children with a detected PTEN mutation are also diagnosed with an autism spectrum disorder [62]. On the other hand, a study comparing autistic children with PTEN mutation and idiopathic ASD showed significantly larger head circumference in patients with PTEN mutation, even compared to idiopathic ASD with macrocephaly (Cowden syndrome, characterized by macrocephaly, is one of PHTS). Moreover, no significant behavioral and cognitive differences were found between groups of children with ASD [63].

\section{Discussion}

It is estimated that autism spectrum disorders affect 1 in 54 children of all racial, ethnic and socioeconomic groups [64]. There are many potential causes of ASD, but most researchers agree that genetic factors play a significant role in the development of this disease. So far, however, it has not been possible to identify one gene or a group of genes directly responsible for the development of autistic disorders. Instead, researchers are finding more and more genetic factors that correlate with ASD in patients.

Among them, it was possible to distinguish the SHANK family of genes, which are related to cognitive functioning, communication and social interactions. The researchers' interest is primarily the SHANK3 gene - the most frequently mutating gene in the family and causing the most severe cognitive impairment. It turns out that the use of romidepsin and CLK2 inhibitors may be helpful in restoring social functions in carriers of the SHANK3 mutation.

Many studies have also shown the relationship of genes responsible for controlling intracellular calcium levels with the development of autism spectrum disorders. High throughput of calcium signaling turned out to be correlated with the occurrence of symptoms of autism. The group of IP3R calcium channels is of particular interest, as signaling in the nervous system mediated by it is disturbed in most cases of ASD.

Similarly, the area of the short arm of chromosome 7 is examined, where many mutations correlated with the occurrence of autism spectrum disorders are found. Genes such as AUTS2, GNAI1 or RELN are very likely to be potentially responsible for the development of autism. The KMT2E and KMT2C genes are also identified as containing variants that may affect the risk of ASD. The latest research also indicates the BRAF gene, present in many cancers, as co-responsible for the occurrence of autism. The relationship has not been demonstrated for the FOXP2 gene, however, its interaction with MAOA may be associated with language disorders typical of autism.

Research is also focused on other genetic disease syndromes. It turns out that in some of them - fragile $\mathrm{X}$ chromosome syndrome, PTEN hamartoma tumor syndromes, tuberous sclerosis - autism occurs several dozen times more often than in the general population. Other syndromes that attract researchers' attention are Timothy syndrome and Rett's syndrome, in which patients present symptoms very similar to those of autism 
spectrum disorders, which may be helpful in identifying the genes responsible for these changes in ASD.

Research into the genetic basis of autism is ongoing. Their results will help to better understand the pathophysiology of this disease and possibly contribute to the development of new targeted therapies for ASD patients.

\section{Conclusions}

Despite the progress of medical knowledge and the undoubted increase in popular awareness of neurodevelopmental disorders, medicine still does not know the answers to the questions about the genetic determinants of autism. There are many hypotheses about the emergence of autism, the human genome is constantly being tested, and the search for genetic markers of this disorder is ongoing. In recent years, researchers have been intensively trying to establish a gene, a group of genes, or the compilation of various genes with other environmental factors in order to approximate the etiopathogenesis of neurodevelopmental disorders and to create a targeted therapy.

\section{Wstęp}

Spektrum zaburzeń autystycznych (ang. autism spectrum disorder, ASD) obejmuje szereg różnych zaburzeń neurorozwojowych występujących we wczesnym dzieciństwie i objawiających się trudnościami w utrzymaniu relacji, komunikacji oraz ograniczonymi, powtarzalnymi zachowaniami [1]. Badania epidemiologiczne wskazują na występowanie tego zaburzenia u 0,62\%-0,70\% populacji, jednakowoż najnowsze szacunki wskazują na odsetek dochodzący do $2 \%$. Autyzm dotyka od 4 do 5 razy więcej chłopców niż dziewcząt. Patogeneza tej choroby jest złożona. Badacze wskazują na występowanie zarówno czynników genetycznych, środowiskowych oraz interakcji przyczyn genetycznych i środowiskowych, które prowadzą do rozwoju u dziecka zaburzeń ze spektrum autyzmu [2]. Niniejsza praca opisuje najważniejsze czynniki genetyczne, dotychczas zidentyfikowane, mogące przyczyniać się do nieneurotypowego rozwoju, skutkującego zaburzeniami ze spektrum autyzmu.

\section{Materiał i metody}

W celu dokonania analizy światowej bibliografii tematu przeszukano bazę pełnotekstową Pubmed ostatnich lat 17. Posłużono się słowami kluczowymi: autyzm, SHANK, sygnalizacja wapniowa, 7q, choroby monogenowe, zaburzenia genetyczne. Uzyskano wyniki wyszukiwania 43 artykułów pełnotekstowych. Na tej podstawie dokonano opisu najnowszych badań $\mathrm{z}$ dziedziny genetyki i autyzmu.

\section{Dane z analizy}

Dane z analizy

Na rodzinę genów SHANK składają się: SHANK1 (19q13.33), SHANK2 (11q13.2) i SHANK3 (22q13.3). Są to geny kodujące duże białka szkieletowe - składowe kompleksów gęstości postsynaptycznej (ang. postsynaptic density, PSD) w mózgu. W badaniach na gryzoniach wykazano, iż mają one związek $\mathrm{z}$ prawidłowym funkcjonowaniem kognitywnym, pobudliwością, komunikacją oraz interakcjami społecznymi [3]. Ich mutacje odpowiadają za $\sim 1 \%$ przypadków autyzmu i były znajdowane u pacjentów z całego spektrum ASD [4]. Dodatkowo dane z literatury wskazują, że poza autyzmem zaburzenia w obrębie rodziny genów SHANK mogą być przyczyną też innych chorób takich jak schizofrenia, choroba Alzheimera, choroba afektywna dwubiegunowa [3].

Eksperymenty przeprowadzane na myszach pokazują, że w zależności od tego, który z genów zostanie uszkodzony pojawiać się będą różne zmiany zachowania u badanych zwierząt. W przypadku selektywnego uszkodzenia SHANK1 dochodzi do zmniejszenia stopnia zaangażowania $\mathrm{w}$ interakcje społeczne oraz do poważnego upośledzenia zdolności rozpoznawania obiektów [5], jednocześnie badanie przeprowadzone na myszach przez Ha i wsp. pokazało, że gen SHANK2, jest najprawdopodobniej związany $\mathrm{z}$ koordynacją motoryczną i specyficznymi, powtarzalnymi i lękowymi zachowaniami ale nie z typowo autystycznymi objawami takimi jak trudności w nawiązaniu relacji społecznych czy stałe powtarzanie tych samych czynności [6]. Opisana po raz pierwszy w zespole Phelana-McDermida (delecja 22q13.3), który charakteryzuje się ogólnym opóźnieniem rozwoju [7], mutacja SHANK3 jest uważana za powodującą najcięższe zaburzenia poznawcze ze wszystkich genów z rodziny SHANK. Występuje ona również częściej niż mutacje dwóch pozostałych genów SHANK [4]. Badania przeprowadzone przez Pagani i wsp. wykazały, że nosicielstwo mutacji SHANK3 wiąże się z upośledzeniem funkcji kory przedczołowej, które to badacze wiążą bezpośrednio $\mathrm{z}$ występowaniem deficytu społecznokomunikacyjnego [8]. Podobnie przeprowadzone przez Peça i wsp. badanie polegające na wytworzeniu dwóch linii myszy z różnymi uszkodzeniami SHANK3 potwierdziło osłabienie u gryzoni zachowań społecznych w stopniu zależnym od fragmentu genu, który był uszkodzony [9].

Lepsze poznanie związku mutacji genów SHANK z rozwojem ASD może przyczynić się do opracowania 
celowanych $\mathrm{w}$ te mutacje metod leczenia zaburzeń ze spektrum autyzmu. Badanie przeprowadzone przez Qin i wsp. wykazało skuteczność stosowania romidepsyny (inhibitora deacetylazy histonów klasy I) w łagodzeniu deficytu zachowań społecznych u myszy z niedoborem SHANK3 [10]. Podobnie badacze pod kierownictwem Bidinosti wykazali skuteczność inhibitorów CDC-podobnej kinazy 2 (ang. CDC-like kinase 2, CLK2) w przywracaniu funkcji społecznych u myszy z ubytkiem SHANK3 [11].

\section{Geny kodujace kanały wapniowe}

Wiele badań wykazało, że za zaburzenia ze spektrum autyzmu często odpowiadają geny związane pośrednio lub bezpośrednio z kontrolowaniem wewnątrzkomórkowego poziomu jonów wapnia lub białkami regulowanymi przez wzrost wewnątrzkomórkowego poziomu wapnia. Geny te kodują kanały jonowe, receptory dla neuroprzekaźników i regulowane jonami wapnia białka sygnałowe kluczowe dla rozwoju ośrodkowego układu nerwowego [12].

W neuronach kanały wapniowe są szczególnie ważne w inicjowaniu i propagacji działania potencjałów. Kiedy potencjał dociera do błony presynaptycznej, lokalne napięciozależne receptory wapniowe otwierają się, powodując napływ jonów wapnia wzmocniony przez uwolnienie wewnątrzkomórkowych zapasów wapnia. Prowadzi to do fuzji pęcherzyków zawierających neuroprzekaźniki z błoną presynaptyczną powodując uwolnienie neuroprzekaźnika do przestrzeni synaptycznej [13].

W ostatnich latach zostało wykonane badanie mające na celu zbadać korelację między wysoką przepustowością sygnalizacji wapniowej a objawami ASD (badanymi testem ADOS-2 będącym złotym standardem w wykrywaniu autyzmu). Została wykonana krzywa ROC będąca oceną jakości klasyfikatora. Wynik AUC równy 0.85 wskazuje że analiza sygnalizacji wapniowej może być wiarygodnym testem diagnostycznym w tych zaburzeniach, chociaż potrzeba dodatkowych badań kohortowych z użyciem większych grup pacjentów [13].

Szczególną rolę badania przypisały grupie kanałów wapniowych IP3R. W komórce największe ich zagęszczenie występuje $\mathrm{w}$ siateczce śródplazmatycznej będącej głównym magazynem wewnątrzkomórkowego wapnia. Kanały te składają się z trzech produktów różnych genów (IP3Rs typy 1-3). W neuronach uwalnianie wapnia pośredniczone przez IP3R ma wpływ na plastyczność i pamięć synaptyczną [14, 15], pobudliwość neuronów $[16,17]$, uwalnianie neuroprzekaźników [18, 19], wzrost aksonów [20] i długotrwałe zmiany w ekspresji genów [18]. W zależności od części mózgowia ekspresji ulegają w różnym stopniu różne izoformy IP3R. Na przykład komórki Purkinjego w móżdżku cechuje wysoka ekspresja IP3R1, ale mają niski lub niewykrywalny poziom IP3R3.
Natomiast komórki ziarniste móżdżku i wiele regionów rdzenia wykazują umiarkowanie wysokie poziomy IP3R3, podczas gdy IP3R1 jest praktycznie niewykrywalny w tych regionach [13]. IP3R wykazuje wysoki poziom ekspresji w móżdżku i tam właśnie został po raz pierwszy przez naukowców wykryty. Co ciekawe, dysfunkcje móżdżku bywały w badaniach wiązane z autyzmem [21]. Odkrycia omówione w jednym z przeglądów wskazują, że sygnalizacja, w której pośredniczy IP3R, jest zaburzona w większości przypadków ASD, wskazując siateczkę śródplazmatyczną jako funkcjonalne „centrum”, w którym różne szlaki sygnalizacji komórkowej zbiegają się, przyczyniając się do patogenezy [13].

\section{Zwiq̨zek mutacji w regionie $7 q$ z występowaniem autyzmu.}

Chromosom 7 jest zaliczany do chromosomów submetacentrycznych, a więc posiadających centromer w pobliżu środka chromosomu. Oznacza to, że jego ramiona górne - p są krótsze od ramion dolnych- q [22]. Jedno z pierwszych badań łączących autyzm z ramieniem q chromosomu 7 zostało przeprowadzone w 1989 r. przez Molecular Genetic study Autism Consortium [23]. Kolejne badania doprowadziły do odkrycia rejonów, których mutacje mogą w znacznym stopniu być odpowiedzialne za wystąpienie autyzmu.

W regionie 7q11.22 znajduje się gen AUTS2 [24] którego funkcja w ludzkim organizmie nadal jest niewystarczająco poznana. Badania na myszach wykazały, że jego silna ekspresja w ciele płodu jest obserwowana $w$ obszarach związanych z funkcjami wyższymi mózgu, to jest korze nowej, hipokampie oraz móżdżku, a także, iż bierze on udział w formowaniu się rdzenia kręgowego [25]. Jego poprawne funkcjonowanie jest niezbędne do prawidłowej migracji neuronów i rozwoju kory [26]. Zaburzenie jego funkcji związane jest z występowaniem padaczki [27], opóźnieniem rozwoju [28] i autyzmem. W szczególności ta ostatnia choroba znajduje potwierdzenie w najnowszych badaniach. Istnieją przesłanki, że mutacje genu AUTS2 mogą istotnie przyczyniać się do wystąpienia autyzmu. Według badania Husson i wsp. AUTS2 został zakwalifikowany do klasy B. $(10 \%<$ FDR $<5 \%)$, co oznacza, że prawdopodobnie związany on jest z występowaniem autyzmu. Warto dodać, że gen zawiera region o statystycznie największym znaczeniu w różnicowaniu Homo sapiens od neandertalczyków i innych naczelnych. Gen ten uległ więc dużej zmianie podczas ewolucji gatunku ludzkiego [29].

Gen GNAI1 znajduje się w regionie 7q21.11 [30]. Kodowane przez niego białko stanowi podjednostkę alfa kompleksu hamującego, który odpowiada na sygnały betaadrenergiczne poprzez hamowanie cyklazy adenylowej. Badanie Satterstrom i wsp. zidentyfikowało ten gen jako kandydata mogącego przyczyniać się do wystąpienia 
autyzmu z fałszywym wskaźnikiem wykrywalności (FDR) pomiędzy 0.01 and 0.05 (0.01 < FDR 0.05) - istnieje 95\% szans na dodatnią korelację [31].

W regionie 7q22.1 znajdują się geny RELN oraz GIGYF1 [32]. Funkcją genu RELN jest w głównej mierze kontrola migracji neuronów i ich pozycjonowania podczas rozwoju ośrodkowego układu nerwowego [33]. De Rubeis i wsp. analizując 3,871 pacjentów wykazali, że istnieje 95\% szansy skorelowania genu RELN z autyzmem [34].

Gen KMT2E znajduje się w regionie 7q22.3 [35]. Stwierdzono, że odgrywa kluczową rolę $\mathrm{w}$ wielu procesach biologicznych, w tym w cyklu komórkowym, utrzymaniu stabilności genomu, hematopoezie dorosłych i spermatogenezie [36]. Spekuluje się, że może mieć znaczny udział w rozwoju kory mózgowej, gdyż jego ekspresja jest się na wysokim poziomie w życiu prenatalnym [37], a jego mutacja może przyczyniać się do wystąpienia autyzmu u ludzi nią obciążonych [38].

Podobnie gen KMT2C [39], który w ludzkim organizmie koduje histonowo-lizynową N-metylotransferazę 2C, która dołącza jedną grupę metylową do lizyny 4 histonu $\mathrm{H} 3$, prowadząc przez to do aktywacji transkrybcji. Funkcja molekularna KMT2C była eksplorowana poprzez badanie jego ortologów (trr i G9a) u mchówek Drosophila [40]. KMT2C został również zidentyfikowany $\mathrm{w}$ badaniu sekwencjonowania całego egzomu ASD i późniejszej analizie statystycznej wariacji przekazanych i de novo (ang. transmission and de novo association, TADA) jako gen silnie wzbogacony w warianty, które mogą wpływać na ryzyko ASD z fałszywym współczynnikiem wykrywalności (FDR) $<0,1$ [34].

W rejonie 7q31.1 znajduje się gen FOXP2, który dostarcza informacji niezbędnych do syntezy białka forkhead box P2. Jest ono aktywne zarówno w życiu prenatalnym jak i postnatalnym w mózgu. Badania sugerują, że ma ono istotne znaczenie w jego rozwoju wliczając w to wpływ na wzrost neuronów i transmisję sygnałów między nimi, a także na ich plastyczność (zdolność do tworzenia nowych połączeń między neuronami, niezbędna $w$ procesie uczenia się). Wydaje się też, iż gen ten odgrywa istotną rolę w rozwoju mowy i języka [41]. Aktywacja FOXP2 zachodzi na drodze degradacji serotoniny, poprzez monoaminoksygenazę A, kodowaną przez gen MAOA. Mutacja tego genu prowadząca do zmniejszenia prze niego kodowanej monoaminooksygenazy oraz mutacja FOXP2 występujące razem są związane z występowaniem autyzmu. Korelacja nie zachodzi, jeśli mutacje te występują osobno [42].

Gen BRAF (zlokalizowany w regionie 7q34) w organizmie człowieka odpowiada za kodowanie białka należącego do rodziny serynowo-treoninowych kinaz białkowych raf/mil.[43]. Jego mutacje związane są głównie z zespołem sercowo-twarzowo-skórnym, który objawia się wadami serca, opóźnieniem rozwoju i deformacjami twarzoczaszki [44], jak również ze zwiększoną częstotliwością nowotworów, między innymi chłoniaków. Jedne z najnowszych badań wskazuje, że zmiany w obrębie tego genu, mogą przyczynić się w istotny sposób do występowania autyzmu [31]

\section{ASD w jednogenowych zespołach chorobowych}

Zaburzenia ze spektrum autyzmu są obecne w wielu zespołach jednogenowych, zaś u około $10 \%$ ludzi z ASD stwierdzane są objawy spełniające kryteria zespołu chorobowego spowodowanego pojedynczą mutacją [45].

\section{Zespół łamliwego chromosomu X - FMR1}

Jednym z przykładów jest zespół łamliwego chromosomu X, zwany zespołem Martina Bell. 25\% ludzi z tym zespołem wykazuje zaburzenia ze spektrum autyzmu [46]. Odpowiada za niego mutacja dynamiczna w genie FMR1, polega ona na powieleniu segmentu genu o sekwencji trzech nukleotydów CGG. Jeśli ilość powtórzeń wynosi 65-200 jest to premutacja nie dająca zwykle objawów choroby, ale mająca tendencję do wydłużania się w kolejnych pokoleniach. Jeśli ilość powtórzeń przekroczy 200, wówczas jest to pełna mutacja dająca objawy u wszystkich obciążonych nią chłopców i około połowy dziewczynek. Gen ten koduje białko FMRP, w największym stopniu obecne w mózgu, które jest niezbędne do prawidłowego rozwoju umysłowego oraz płodności u kobiet. Jego rola polega na regulacji transportu i translacji mRNA w mózgu co ma duże znaczenie w plastyczności synaps. FMR1 jest jednym $\mathrm{z}$ trzech zbadanych genów związanych z autyzmem który zwiększa swoją ekspresję w wieku niemowlęcym i dzieciństwie [46]. Jedno z badań wykryło nowy wariant mutacji braku sensu w genie FMR1. Znajduje się ona w domenie NES tego genu i prowadzi do akumulacji białka, prawdopodobnie zaburzając przedział postsynaptyczny w neuronach. Chłopiec u którego wykryto mutacje był opóźniony intelektualnie, miał problemy w kontaktach międzyludzkich i zaburzenia zachowania [47].

\section{Zespół Timothy'ego - CACNA1C}

Rzadka jednostka chorobowa, zespół Timothy’ego, jest wynikiem mutacji $w$ genie CACNA1C. Jest to gen zlokalizowany na 12 . chromosomie i odpowiada za tworzenie jednego $\mathrm{z}$ kanałów wapniowych. Mutacja powoduje zaburzenie funkcji tego kanału, co skutkuje przede wszystkim groźnymi arytmiami prowadzącymi zwykle do śmierci we wczesnym dzieciństwie [48]. Z pacjentów, którzy przeżyli dostatecznie długo do postawienia diagnozy - 60-80\% prezentowało cechy 
autyzmu [46]. Również mutacje w innych genach $\mathrm{z}$ tej rodziny (CACNA1D-CACNA1H) są odpowiedzialne za różne dysfunkcje związane z autyzmem $[49,50]$.

\section{Stwardnienie guzowate - TSC1 i TSC2}

W przypadku chorych na stwardnienie guzowate, które objawia się występowaniem licznych zmian narządowych zwykle o charakterze hamartomy lub hamartii odsetek osób z autyzmem wynosi około $20 \%$. Jest to choroba genetyczna wynikająca z mutacji utraty funkcji genów TSC1 oraz TSC2. Geny te działają jako inhibitory kompleksu mTOR - kinazy której funkcją jest regulacja wzrostu, proliferacji i ruchu komórki jak i procesów translacji i transkrypcji. Szlak mTOR jest kluczowy w kontrolowaniu lokalnej translacji w synapsach [45].

\section{Zespół Retta - MECP2}

Zespół Retta jest chorobą uwarunkowaną genetycznie, w głównej mierze sprzężoną z chromosomem X. Charakteryzuje się występowaniem zaburzenia rozwoju układu nerwowego, układu ruchu oraz pokarmowego [51]

Występuje z częstością 1 na 10,000 do 15,000. Badania populacyjne przeprowadzone $\mathrm{w}$ stanie Texas (USA), donosiły, że występuje z częstością 1 na 22,800 kobiet od lat 2 do 18 [51]. Początkowo sądzono, że występuje tylko u kobiet, a u mężczyzn stanowi chorobę letalną, jednak najnowsze badania wskazują, że może występować również u mężczyzn [52], jednak objawy rozwijają się u nich szybciej i chorują oni ciężej niż kobiety. Niekiedy może być związany z zepołem Klinefeltera - tacy mężczyźni mają objawy nasilone w stopniu podobnym do chorych kobiet [53].

W 1999 roku, Hudy Zoghbi [54] odkryła, iż główną przyczyną zespołu Retta (bo aż w 95\% przypadkach) jest mutacja w genie MECP2 zlokalizowanym na chromosomie $\mathrm{X}$ w regionie q28 [55]. W 90\% przypadków jest to odziedziczona mutacja, w pozostałych przypadkach wywołana jest przez mikrodelecje i mikroduplikacje regionów krytycznych na chromosomie X. Mechanizm w jakim mutacja w genie MECP2 prowadzi do zespołu Retta jest nadal nieznana [55].

Wykazano, że białko MECP2 w określonych warunkach pobudza ekspresję genu kodującego mózgowo-pochodny czynnik neutropowy, niezbędny do funkcjonowania układu nerwowego zarówno u dorosłych, oraz płodów gdzie bierze udział w utrzymaniu prawidłowej neurogenezy. Zaburzenie ekspresji MECP2 ma negatywny wpływ na formowanie się i stabilizacje synaps - plastyczność synaptyczną - odpowiedzialną w głównej mierze za procesy nauki i pamięci [56].

U pacjentów obserwuje się przez okres pierwszych 6-18 miesięcy po urodzeniu, prawidłowy rozwój układu nerwowego i psychiczny. Choroba zaczyna manifestować się po tym okresie - charakteryzuje się kilkoma etapami: stagnacji (6-18 miesięcy), nagłej progresji (1-4 rok życia), pseudostacjonarny (wiek przedszkolny i szkolny), faza stabilizacji (od 15 roku życia do śmierci). Charakterystycznymi objawami zespołu Retta są: utrata wcześniej nabytej zdolności mówienia i zdolności motorycznych. Pojawiają się stereotypowe ruchy rąk zaburzenia oddychania i drgawki [57].

U takich pacjentów obserwuje się objawy podobne do autyzmu: wycofanie społeczne (w fazie regresji), unikanie kontaktu wzrokowego [58], dlatego wcześniej zaliczano go do chorób ze spektrum autyzmu [59]. Nowsze badania wskazują na różnice miedzy tymi dwom chorobami. Autyzm częściej występuje u mężczyzn, pacjenci na niego chorujący mają zdecydowanie gorszy kontakt wzrokowy z innymi ludźmi i ulegają w znacznie mniejszym stopniu regresji. Zdolności chodu tych pacjentów oraz zdolności manualne w przeciwieństwie do pacjentów z zespołem Retta nie ulegają zaburzeniu. Również bardzo rzadko dochodzi u tych pacjentów do zaburzeń oddychania [58].

\section{Zespoły guzów hamartomatycznych zwiq̨zanych z mutacjami PTEN}

Zespoły guzów hamartomatycznych związanych $\mathrm{z}$ PTEN (ang. PTEN hamartoma tumor syndromes, PHTS) to grupa rzadkich zespołów klinicznych odznaczających się mutacjami linii germinalnej w genie supresorowym PTEN. W PHTS poprzez przerost komórek dochodzi do powstania łagodnych zmian hamartomatycznch w bardzo wielu narządach [60]. Ostanie badania wykazały, iż u 25$50 \%$ dzieci z wykrytą mutacją PTEN jest diagnozowane również zaburzenie ze spektrum autyzmu [61]. Z kolei badanie porównujące autystyczne dzieci z mutacją PTEN oraz idiopatycznym ASD wykazało znacznie większy obwód głowy u pacjentów z mutacją PTEN, nawet $\mathrm{w}$ porównaniu do idiopatycznego ASD z makrocefalią (zespół Cowden, odznaczający się makrocefalią jest jednym z PHTS). Poza tym nie wykazano znaczących różnic behawioralnych i poznawczych pomiędzy grupami dzieci z ASD [62].

\section{Dyskusja}

Szacuje się, że zaburzenia za spektrum autyzmu dotykają 1 na 54 dzieci ze wszystkich rasowych, etnicznych i socjoekonomicznych grup [63]. Istnieje wiele potencjalnych przyczyn ASD, jednakowoż większość badaczy jest zgodna, iż niebagatelną rolę w rozwoju tej choroby odgrywają czynniki genetyczne. Jak dotąd nie udało się wskazać jednego genu lub grupy genów bezpośrednio odpowiedzialnych za powstawanie zaburzeń autystycznych. Zamiast tego badacze odnajdują coraz to nowe czynniki genetyczne, które są skorelowane z występowaniem ASD u pacjentów. 
Wśród nich udało się wyodrębnić rodzinę genów SHANK, które związane są $\mathrm{z}$ funkcjonowaniem kognitywnym, komunikacją oraz interakcjami społecznymi. Zainteresowanie badaczy budzi przede wszystkim gen SHANK3 - najczęściej mutujący gen z rodziny i powodujący najcięższe zaburzenia poznawcze. Okazuje się, że stosowanie romidepsyny i inhibitorów CLK2 może być pomocne w przywróceniu funkcji społecznych u nosicieli mutacji SHANK3.

Wiele badań wykazało również związek genów odpowiedzialnych za kontrolowanie wewnątrzkomówkowego poziomu wapnia z rozwojem zaburzeń ze spektrum autyzmu. Wysoka przepustowość sygnalizacji wapniowej okazała się być skorelowana z występowaniem objawów autyzmu. Szczególną uwagę zwraca grupa kanałów wapniowych IP3R, gdyż sygnalizacja w układzie nerwowym, w której on pośredniczy jest zaburzona w większości przypadków ASD.

Podobnie badany jest obszar krótkiego ramienia chromosomu 7. Gdzie odnajdywanych jest wiele mutacji skorelowanych z występowaniem zaburzeń ze spektrum autyzmu. Geny takie jak AUTS2, GNAI1 czy RELN są z bardzo dużym prawdopodobieństwem wskazywane jako potencjalnie odpowiedzialne za rozwój autyzmu. Również geny KMT2E i KMT2C są identyfikowane jako zawierające warianty, które mogą wpływać na ryzyko ASD. Najnowsze badania wskazują również na występujący w wielu nowotworach gen BRAF jako na współodpowiedzialny za występowanie autyzmu. Związku nie wykazano zaś dla genu FOXP2, jednakże jego interakcja z MAOA może być związana z zaburzeniami językowymi typowymi dla autyzmu.

Badania koncentrują się również wokół innych genetycznych zespołów chorobowych. Okazuje się, że w części z nich - zespół łamliwego chromosomu X, zespoły guzów hamartomatycznych związanych z mutacjami PTEN, stwardnienie guzowate - autyzm występuje nawet kilkadziesiąt razy częściej niż w populacji ogólnej. Innymi zespołami przyciągającymi uwagę badaczy są zespół Timothyego oraz zespół Retta, w których pacjenci prezentują objawy bardzo zbliżone do objawów chorób ze spektrum autyzmu, co może być pomocne w odszukaniu genów odpowiedzialnych za te zmiany w ASD.

Badania nad genetycznym podłożem autyzmu trwają. Ich wyniki pomogą lepiej zrozumieć patofizjologię tego schorzenia i być może przyczynią się do opracowania nowych terapii celowanych dla pacjentów dotkniętych ASD.

\section{Wnioski}

Pomimo postępu wiedzy medycznej oraz niewątpliwego wzrostu powszechnej świadomości co do zaburzeń neurorozwojowych, wciąż medycyna nie zna odpowiedzi na pytania dotyczące genetycznych uwarunkowań autyzmu. Istnieje wiele hipotez powstania autyzmu, stale badany jest genom ludzki, trwają poszukiwania genetycznych markerów tego zaburzenia. W ostatnich latach intensywnie trwają starania badaczy co do ustalenia genu, grupy genów, czy też kompilacji różnych genów w połączeniu $\mathrm{z}$ innymi czynnikami środowiskowymi w celu przybliżenia etiopatogenezy zaburzeń neurorozwojowych i stworzenia terapii celowanej.

\section{Conflict of interest}

The authors have declared no conflict of interest.

\section{References:}

1. Lai MC, Lombardo MV, Baron-Cohen S. Autism. Lancet. 2014;383:896-910.

2. Chaste P, Leboyer M. Autism risk factors: genes, environment, and gene-environment interactions. Dialogues Clin Neurosci. 2012;14:281-292.

3. Guilmatre A, Huguet G, Delorme R, Bourgeron T. The emerging role of SHANK genes in neuropsychiatric disorders. Dev Neurobiol. 2014;74:113-122.

4. Leblond CS, Nava C, Polge A, Gauthier J, Huguet G, Lumbroso S et al. Meta-analysis of SHANK Mutations in Autism Spectrum Disorders: a gradient of severity in cognitive impairments. PLoS Genet. 2014;10:e1004580.

5. Mossa A, Giona F, Pagano J, Sala C, Verpelli C. SHANK genes in autism: Defining therapeutic targets. Prog Neuropsychopharmacol Biol Psychiatry. 2018;84:416-423.

6. Ha S, Lee D, Cho YS, Chung C, Yoo YE, Kim J et al. Cerebellar Shank2 Regulates Excitatory Synapse Density, Motor Coordination, and Specific Repetitive and Anxiety-Like Behaviors. J Neurosci. 2016;36:12129-12143.

7. Costales JL, Kolevzon A. Phelan-McDermid Syndrome and SHANK3: Implications for Treatment. Neurotherapeutics. 2015;12:620-630.

8. Pagani M, Bertero A, Liska A, Galbusera A, Sabbioni M, Barsotti $\mathrm{N}$ et al. Deletion of Autism Risk Gene Shank3 Disrupts Prefrontal Connectivity. J Neurosci. 2019;39:5299-5310.

9. Peça J, Feliciano C, Ting JT, Wang W, Wells MF, Venkatraman TN et al. Shank3 mutant mice display autistic-like behaviours and striatal dysfunction. Nature. 2011;472:437-442.

10. Qin L, Ma K, Wang ZJ, Hu Z, Matas E, Wei J et al. Social deficits in Shank3-deficient mouse models of autism are rescued by histone deacetylase (HDAC) inhibition. Nat Neurosci. 2018;21:564-575.

11. Bidinosti M, Botta P, Krüttner S, Proenca CC, Stoehr N, Bernhard $\mathrm{M}$ et al. CLK2 inhibition ameliorates autistic features associated with SHANK3 deficiency. Science. 2016;351:1199-1203.

12. Krey JF, Dolmetsch RE. Molecular mechanisms of autism: a possible role for $\mathrm{Ca} 2+$ signaling. Curr Opin Neurobiol. 2007;17:112-119.

13. Nguyen RL, Medvedeva YV, Ayyagari TE, Schmunk G, Gargus JJ. Intracellular calcium dysregulation in autism spectrum disorder: An analysis of converging organelle signaling pathways. Biochim Biophys Acta Mol Cell Res. 2018;1865:17181732.

14. Rose CR, Konnerth A. Stores not just for storage. intracellular calcium release and synaptic plasticity. Neuron. 2001 Aug 
30;31(4):519-22.

15. Inoue $\mathrm{T}$, Kato $\mathrm{K}$, Kohda $\mathrm{K}$, Mikoshiba $\mathrm{K}$. Type 1 inositol 1,4,5-trisphosphate receptor is required for induction of longterm depression in cerebellar Purkinje neurons. J Neurosci. 1998;18:5366-5373.

16. Hernandez-Lopez S, Tkatch T, Perez-Garci E, Galarraga E, Bargas J, Hamm $\mathrm{H}$ et al. D2 dopamine receptors in striatal medium spiny neurons reduce L-type $\mathrm{Ca} 2+$ currents and excitability via a novel PLC[beta]1-IP3-calcineurin-signaling cascade. J Neurosci. 2000;15;20(24):8987-95.

17. Stutzmann GE, LaFerla FM, Parker I. Ca2+ signaling in mouse cortical neurons studied by two-photon imaging and photoreleased inositol triphosphate. J Neurosci. 2003;23:758765.

18. Li YX, Zhang Y, Lester HA, Schuman EM, Davidson N. Enhancement of neurotransmitter release induced by brainderived neurotrophic factor in cultured hippocampal neurons. J Neurosci. 1998;18:10231-10240.

19. Diamant S, Schwartz L, Atlas D. Potentiation of neurotransmitter release coincides with potentiation of phosphatidyl inositol turnover. A possible in vitro model for long term potentiation. Neurosci Lett. 1990;109:140-145.

20. Gomez TM, Spitzer NC. In vivo regulation of axon extension and pathfinding by growth-cone calcium transients. Nature. 1999;397:350-355.

21. Wang SS, Kloth AD, Badura A. The cerebellum, sensitive periods, and autism. Neuron. 2014;83:518-532.

22. Ferenc T, Mordalska A, Bratkowska. Cytogenetyka. W: Drewa G, Ferenc T. red. Genetyka medyczna. Wrocław; Edra Urban \& Partner: 2011

23. A full genome screen for autism with evidence for linkage to a region on chromosome 7q. International Molecular Genetic Study of Autism Consortium. Hum Mol Genet. 1998;7:571-578.

24. SFARI Gene [strona w Internecie]. Simons Foundation Autism Research Initiative. AUTS2 autism susceptibility candidate 2 [cytowana 28 lipca 2021]. Dostępna z: https://gene.sfari.org/ database/human-gene/AUTS2

25. Bedogni F, Hodge RD, Nelson BR, Frederick EA, Shiba N, Daza RA et al. Autism susceptibility candidate 2 (Auts2) encodes a nuclear protein expressed in developing brain regions implicated in autism neuropathology. Gene Expr Patterns. 2010;10(1):9-15.

26. Hori K, Nagai T, Shan W, Sakamoto A, Taya S, Hashimoto R et al. Cytoskeletal regulation by AUTS2 in neuronal migration and neuritogenesis. Cell Rep. 2014;9:2166-2179.

27. Mefford HC, Muhle H, Ostertag P, von Spiczak S, Buysse K, Baker $\mathrm{C}$ et al. Genome-wide copy number variation in epilepsy: novel susceptibility loci in idiopathic generalized and focal epilepsies. PLoS Genet. 2010;6:e1000962.

28. Nagamani SC, Erez A, Ben-Zeev B, Frydman M, Winter S, Zeller $\mathrm{R}$, et al. Detection of copy-number variation in AUTS2 gene by targeted exonic array CGH in patients with developmental delay and autistic spectrum disorders. Eur J Hum Genet. 2013;21(3):343-6.

29. Oksenberg N, Stevison L, Wall JD, Ahituv N. Function and regulation of AUTS2, a gene implicated in autism and human evolution. PLoS Genet. 2013;9:e1003221.

30. SFARI Gene [strona w Internecie]. Simons Foundation Autism Research Initiative. GNAI1 G protein subunit alpha i1 [cytowana 28 lipca 2021]. Dostępna z: https://gene.sfari.org/database/ human-gene/GNAI1

31. Satterstrom FK, Kosmicki JA, Wang J, Breen MS, De Rubeis S, An JY et al. Large-Scale Exome Sequencing Study Implicates Both Developmental and Functional Changes in the Neurobiology of
Autism. Cell. 2020;180:568-584.e23.

32. SFARI Gene [strona w Internecie]. Simons Foundation Autism Research Initiative. RELN Reelin [cytowana 28 lipca 2021]. Dostępna z: https:/gene.sfari.org/database/human-gene/ RELN

33. Huang CC., D’Arcangelo G. The Reelin Gene and Its Functions in Brain Development. W: Fatemi S.H. red. Reelin Glycoprotein. New York; Springer: 2008

34. De Rubeis S, He X, Goldberg AP, Poultney CS, Samocha K, Cicek AE et al. Synaptic, transcriptional and chromatin genes disrupted in autism. Nature. 2014;515:209-215.

35. SFARI Gene [strona w Internecie]. Simons Foundation Autism Research Initiative. KMT2E Lysine (K)-specific methyltransferase 2E [cytowana 28 lipca 2021]. Dostępna z: https://gene.sfari.org/database/human-gene/KMT2E

36. Zhang X, Novera W, Zhang $Y$, Deng LW. MLL5 (KMT2E): structure, function, and clinical relevance. Cell Mol Life Sci. 2017;74:2333-2344.

37. Conforti R, Iovine S, Santangelo G, Capasso R, Cirillo M, Fratta M et al. ODLURO syndrome: personal experience and review of the literature. Radiol Med. 2021;126:316-322.

38. Wang T, Hoekzema K, Vecchio D, Wu H, Sulovari A, Coe BP et al. Large-scale targeted sequencing identifies risk genes for neurodevelopmental disorders. Nat Commun. 2020;11:4932.

39. SFARI Gene [strona w Internecie]. Simons Foundation Autism Research Initiative. KMT2C Lysine (K)-specific methyltransferase 2C [cytowana 28 lipca 2021]. Dostępna z: https://gene.sfari.org/database/human-gene/KMT2C

40. Lavery, WJ, Barski A., Wiley S, Schorry EK, Lindsley AW. KMT2C/D COMPASS complex-associated diseases [KCDCOM-ADs]: an emerging class of congenital regulopathies. Clin Epigenet 2020;12, 10

41. National Center for Biotechnology Information [strona w Internecie]. U.S. National Library of Medicine. FOXP2 forkhead box P2 [ Homo sapiens (human) ] [aktualizowana 26 lipca 2021; cytowana 28 lipca 2021]. Dostępna z: https://www.ncbi.nlm. nih.gov/gene/93986

42. Park Y, Won S, Nam M, Chung JH, Kwack K. Interaction between MAOA and FOXP2 in association with autism and verbal communication in a Korean population. J Child Neurol. 2014;29(12):NP207-11.

43. MedlinePlus [strona $\mathrm{w}$ Internecie]. U.S. National Library of Medicine. BRAF gene [aktualizowana 28 maja 2021; cytowana 28 lipca 2021]. Dostępna z: https://medlineplus.gov/genetics/ gene/braf/

44. SFARI Gene [strona w Internecie]. Simons Foundation Autism Research Initiative. BRAF v-raf murine sarcoma viral oncogene homolog B [cytowana 28 lipca 2021]. Dostępna z: https://gene. sfari.org/database/human-gene/BRAF

45. Liu X, Takumi T. Genomic and genetic aspects of autism spectrum disorder. Biochem Biophys Res Commun. 2014;452:244-253.

46. Miyauchi S, Voineagu I. Autism susceptibility genes and the transcriptional landscape of the human brain. Int Rev Neurobiol. 2013;113:303-318.

47. Zeidler S, Severijnen LA, de Boer $H$, van der Toorn EC, Ruivenkamp CAL, Bijlsma EK et al. A missense variant in the nuclear export signal of the FMR1 gene causes intellectual disability. Gene. 2021;768:145298.

48. Splawski I, Timothy KW, Sharpe LM, Decher N, Kumar P, Bloise $\mathrm{R}$ et al. $\mathrm{Ca}(\mathrm{V}) 1.2$ calcium channel dysfunction causes a multisystem disorder including arrhythmia and autism. Cell. 2004;119:19-31.

49. Pinggera A, Lieb A, Benedetti B, Lampert M, Monteleone S, Liedl KR et al. CACNA1D de novo mutations in autism spectrum 
disorders activate Cav1.3 L-type calcium channels. Biol Psychiatry. 2015;77:816-822.

50. O'Roak BJ, Vives L, Girirajan S, Karakoc E, Krumm N, Coe BP et al. Sporadic autism exomes reveal a highly interconnected protein network of de novo mutations. Nature. 2012;485:246-250.

51. Gold WA, Krishnarajy R, Ellaway C, Christodoulou J. Rett Syndrome: A Genetic Update and Clinical Review Focusing on Comorbidities. ACS Chem Neurosci. 2018;9:167-176.

52. Chahil G, Yelam A, Bollu PC. Rett Syndrome in Males: A Case Report and Review of Literature. Cureus. 2018;10:e3414.

53. Krosno D. Zespół Retta - Zaburzenie Neurorozwojowe o Podłożu Genetycznym. W: Buchnat M, Pawelczak K. red. Nieznane? Poznane. - Zaburzenia rozwojowe u dzieci z rzadkimi zespołami genetycznymi i wadami wrodzonymi. Poznań; Wydawnictwo Naukowe UAM: 2011

54. Amir RE, Van den Veyver IB, Wan M, Tran CQ, Francke U, Zoghbi HY. Rett syndrome is caused by mutations in X-linked MECP2, encoding methyl-CpG-binding protein 2. Nat Genet. 1999;23:185-188.

55. Chahil G, Bollu PC. Rett Syndrome. W: StatPearls [Internet]. Treasure Island, Florida; StatPearls Publishing: 2021

56. Fagiolini M, Patrizi A, LeBlanc J, Jin LW, Maezawa I, Sinnett S et al. Intellectual and Developmental Disabilities Research Centers: A Multidisciplinary Approach to Understand the Pathogenesis of Methyl-CpG Binding Protein 2-related Disorders. Neuroscience. 2020;445:190-206.

57. Kyle SM, Vashi N, Justice MJ. Rett syndrome: a neurological disorder with metabolic components. Open Biol. 2018;8

58. Percy AK. Rett syndrome: exploring the autism link. Arch Neurol. 2011;68:985-989.

59. American Psychiatric Association. Diagnostic and statistical manual of mental disorders: DSM-IV [Internet]. 4th ed.
Washington, DC; American Psychiatric Association: 1994

60. Blumenthal GM, Dennis PA. PTEN hamartoma tumor syndromes. Eur J Hum Genet. 2008;16:1289-1300.

61. Frazier TW. Autism Spectrum Disorder Associated with Germline Heterozygous PTEN Mutations. Cold Spring Harb Perspect Med. 2019;9

62. Frazier TW, Embacher R, Tilot AK, Koenig K, Mester J, Eng C. Molecular and phenotypic abnormalities in individuals with germline heterozygous PTEN mutations and autism. Mol Psychiatry. 2015;20:1132-1138.

63. Maenner MJ, Shaw KA, Baio J, EdS, Washington A, Patrick M et al. Prevalence of Autism Spectrum Disorder Among Children Aged 8 Years - Autism and Developmental Disabilities Monitoring Network, 11 Sites, United States, 2016. MMWR Surveill Summ. 2020;69:1-12.

\section{Corresponding author}

Paweł Stanicki

Student Research Group at the I Department of Psychiatry, Psychotherapy and Early Intervention, Medical University of Lublin, Poland stanicki99@gmail.com

Otrzymano: 04.08.2021

Zrecenzowano: 03.10.2021

Przyjęto do druku: 17.11.2021 